Copyright (C) 2021 University of Bucharest Printed in Romania. All rights reserved

ISSN print: $1224-5984$

ISSN online: $2248-3942$
Rom Biotechnol Lett. 2021; 26(2): 2423-2427 doi: $10.25083 / \mathrm{rbl} / 26.2 / 2423.2427$

\title{
Camelina sativa oil can inhibit Campylobacter jejuni but stimulate lactic acid bacteria growth
}

\author{
ȘTEFAN BĂTRÎNA ${ }^{1}$, NICOLAE CORCIONIVOSCHI ${ }^{2}$, STEFANA JURCOANE \\ MARK LINTON ${ }^{2}$, CARMEL KELLY ${ }^{2}$, LAURETTE PINKERTON ${ }^{2}$, ILINCA MERIMA \\ IMBREA $^{1}$, FILIP SIMA ${ }^{2,4}$, FLORIN IMBREA ${ }^{1}$
}

${ }^{1}$ Banat University of Agricultural Sciences and Veterinary Medicine "King Michael I Of Romania", Calea Aradului nr. 119, Timișoara 300645, Romania

${ }^{2}$ Agri-Food and Biosciences Institute, 18a Newforge Lane, Belfast BT9 5PX, United Kingdom

${ }^{3}$ University of Agronomical Sciences and Veterinary Medicine Bucharest, Faculty of Biotechnologies, 59, Mărăsti Blvd, 011464, Romania

${ }^{4}$ University of Bucharest, Faculty of Biology, Bucharest, Romania

\begin{abstract}
Camelina (Camelina sativa L. Crantz) or false flax is an oil crop from the Brassicaceae family. Camelina oil has multiple uses, of which the best known is biofuel production. A motivation for this study was the oil's high content of omega-3, omega- 6 and omega- 9 fatty acids, which are known to have an antimicrobial effect. Campylobacter is the most common bacterial cause of human foodborne gastroenteritis in the world. We tested the potential antimicrobial effect of free fatty acids (FFA) from camelina oil against lactic acid bacteria (LAB) and Campylobacter. The in vitro results show that the free fatty acids from camelina oil reduces levels of Campylobacter spp. and increases the levels of LAB showing a potential use of camelina oil as a natural antimicrobial.
\end{abstract}

Keywords Camelina sativa, oil, campylobacter, lactic acid bacteria, antimicrobial.

To cite this article: BĂTRÎNA Ș, CORCIONIVOSCHI N, JURCOANE S, LINTON M, KELLY C, PINKERTON L, IMBREA IM, SIMA F, IMBRE F. Camelina sativa oil can inhibit Campylobacter jejuni but stimulate lactic acid bacteria growth. Rom Biotechnol Lett. 2021; 26(2): 2423-2427. DOI: $10.25083 / \mathrm{rbl} / 26.2 / 2423.2427$

*Corresponding author: ȘTEFAN BĂTRÎNA, Banat's University of Agricultural Sciences and Veterinary Medicine "King Michael I of Romania" Timişoara, Faculty of Agriculture, 300645, Aradului Street 119, Timişoara, Romania

E-mail: batran.stefan@gmail.com Tel.: 0040725224196 


\section{Introduction}

Camelina, also known as false flax or gold of pleasure, is known to have been cultivated for the first time in Scandinavia. Then it spread to other regions towards the East and South, reaching as far as current day Romania and even further, beyond the Ural Mountains [1]. Camelina (Camelina sativa L. Crantz) has recently drawn a lot of attention due to its oil, which has a high content of omega3 , omega- 6 and omega- 9 fatty acids and has virtually no requirements regarding soil and climate. Also, camelina provides a high value meal with enough residual lipid content $(5-10 \%)$ that has a protein profile similar to soy meal. This makes it ideal as a supplement in rations for poultry and other livestock. [2].

According to WHO (World Health Organization), every year up to $10 \%$ of the population falls ill due to foodborne diseases including Campylobacteriosis. The most common transmission route is believed to be foodborne, Campylobacter being prevalent in food animals like poultry, cattle, pigs etc. [3]. Despite much research, no natural, antibiotic free, nutritional Campylobacter control strategies have been successfully identified and implemented in the meat industry [4]. Many studies have shown that some natural compounds have bioactivity against Campylobacter proliferation, with only a few yielding promising results in animal studies $[4,5,6]$.

Lactic acid bacteria (LAB) are gram-positive microorganisms capable of producing a greater or lesser amount of lactic acid by degradation of various substrates. LAB from intestinal microflora can have beneficial effects, such as increasing competition for nutrients, producing antimicrobial peptides and reducing the survival and growth of harmful bacteria (especially pathogenic); furthermore, they can lower cholesterol. Due to their presence in food and their contribution to the healthy microbiota of mucosal surfaces we also considered the effect of camelina oil on LAB for this study.

Camelina oil contains over $50 \%$ polyunsaturated fatty acids, particularly linoleic and a-linoleic acids [7, 8, 9]. Usually camelina oil has in its composition 21 fatty acids with chain length from $\mathrm{C}-14$ to $\mathrm{C}-24$ depending on climate conditions and on the method and apparatus which was used to determine them [10]. The major fatty acids present are usually $\alpha$-linolenic, linoleic, oleic, eicosenoic and palmitic. All of these fatty acids, except for eicosenoic acid, are known to have an antimicrobial effect [11].

Another attempt of assessing the possible antimicrobial effect of camelina was carried out by a team of researchers from India. By testing seed extracts of camelina on different pathogens, they found that methanolic and ethanolic seed extracts have a significant to intermediate activity against both gram-positive and gramnegative pathogens including Escherichia Coli, with inhibition zones ranging from $10-12$ and $7-9 \mathrm{~mm}$ to 8-14 $\mathrm{mm}$ and 7-9 $\mathrm{mm}$. [12].
There is proof that extracts of other Brassica plants have antimicrobial activity, due to their composition of various bioactive compounds like camalexin, phytic acid flavonols, sinapic acid and glucosinolates. Camalexin has been tested in vitro against various bacteria and fungi with positive results [13] [14], showing an antimicrobial effect by disrupting the cell membrane [15] [16]. Flavonoids such as quercetin are common among Brassica plants. Many researchers propose them as potent antioxidants with antimicrobial effects, which suggests that the flavonoid is able to inactivate microbial adhesion and cell transport proteins [17].

In this study we had a different approach to assessing the antimicrobial effect of Camelina Sativa, by testing the oil in vitro directly on the microbial organism. This involved recreating the physical and chemical conditions of a pig's small intestine.

\section{Materials and Methods}

\section{Strains and culture conditions}

All the bacteria were obtained from AFBI, Food Microbiology Branch culture collection. We used Campylobacter jejuni RCO 39 (a virulent strain isolated from raw chicken), Lactobacillus acidophilus (LA5), Lactobacillus casei ssp. casei (ATCC 393), Lactobacillus plantarum 299, Lactobacillus plantarum 299v, Lactobacillus rhamnosus (LGG), Lactobacillus brevis (NCIMB 8561) and Lactobacillus fermentum (NCIMB 6991).

C. jejuni was grown on Blood Agar Base No. 2 (Oxoid Ltd., United Kingdom) supplemented with 5\% (vol/vol) defibrinated horse blood (Aquilant Scientific N.I.). The strain was grown under microaerophilic conditions at $41.5^{\circ} \mathrm{C}$ in $85 \% \mathrm{~N}_{2}, 5 \% \mathrm{O}_{2}$, and $10 \% \mathrm{CO}_{2}$ in a Don Whitley MACSVA500 microaerophilic workstation (DAVIDSON \& HARDY LTD., United Kingdom) for $48 \mathrm{~h}$. To enumerate viable microorganisms, suitable 10-fold dilutions were made in Maximum Recovery Diluent (MRD) (Oxoid Ltd., United Kingdom). One hundred microliters of each of the 10-fold dilutions were spread on Campylobacter BloodFree Selective Agar Base (Modified CCDA - Preston; Oxoid Ltd., United Kingdom) without any supplement, and plates were incubated under microaerophilic conditions at $41.5^{\circ} \mathrm{C}$ for $48 \mathrm{~h}$.

Lactic acid bacteria (LAB) were grown individually in De Man, Rogosa and Sharp (MRS) broth (Oxoid Ltd., United Kingdom), incubated at $30^{\circ} \mathrm{C}$ for $72 \mathrm{~h}$, and one milliliter of each solution was used to make the lactic acid bacteria mixture. To enumerate viable microorganisms, suitable 10-fold dilutions of the mixture were made in Maximum Recovery Diluent (Oxoid Ltd., United Kingdom). One hundred microliters of each of the 10-fold dilutions were spread on MRS agar (Oxoid Ltd., United Kingdom), and plates were incubated under normal atmospheric conditions at $30^{\circ} \mathrm{C}$ for $48 \mathrm{~h}$.

To assess in vitro the potential antimicrobial activity of camelina oil we simulated the digestion 
conditions of a pig's small intestine in order to release the fatty acids from triglycerides.

In order to recreate the physical and chemical conditions in a pig's small intestine, $13 \mathrm{ml}$ of phosphate buffer $(\mathrm{pH} 6.8)$ and $6 \mathrm{ml}$ of $50 \mathrm{mg} / \mathrm{ml}$ phosphate buffer pancreatin solution. (Sigma-Aldrich 8049-47-6) were mixed a universal tube.

C. jejuni were "harvested "from the surface of the blood agar plates by flooding the plates with Mueller Hinton Broth (Oxoid UK) and scraping off the colonies with a sterile glass spreader. The resulting suspension was adjusted to an $\mathrm{OD}_{600}$ of 0.6. LAB were grown separately in MRS broth (Oxoid, UK). A mixture was prepared containing $1 \mathrm{ml}$ of each species. This mixture was centrifuged for $20 \mathrm{~min}$ at $5250 \mathrm{x} \mathrm{g}$. After centrifugation the bacteria were resuspended in MRD. A $10^{-2}$ dilution of the suspension was made and this was used as the inoculum. For Campylobacter the 0.6 OD suspension was used as the inoculum.

$200 \mu \mathrm{l}$ of the inoculum was added in a universal tube alongside pancreatin, oil and phosphate buffer. $20 \mathrm{ml}$ of solution were used for each replicate, consisting of $13 \mathrm{ml}$ phosphate buffer, $6 \mathrm{ml}$ of pancreatin solution and $1 \mathrm{ml}$ of camelina resulting in a $5 \%$ oil concentration. To determine the initial inoculum level, suitable ten-fold dilutions were prepared in MRD and spread-plated onto either CCDA plates for $C$. jejuni or MRS plates for LAB. CCDA plates were incubated at $41.5^{\circ} \mathrm{C}$ microaerophilically for $48 \mathrm{~h}$, as described previously and MRS plates were incubated aerobically at $37^{\circ} \mathrm{C}$ for $72 \mathrm{~h}$.

The universal tube with the bacterial culture and the pancreatin solution was incubated for 4 hours at $37^{\circ} \mathrm{C}$ on a shaker. In parallel, another universal tube with the same bacterial inoculum was incubated in the pancreatin solution without camelina oil to serve as a control.

After the 4 hours of incubation, suitable ten-fold dilutions were prepared in MRD from both suspensions and were spread-plated onto agar plates as described above.

After the incubation period, bacterial colonies were counted using a Stuart colony counter (Bibby Sterilin, UK).

\section{Statistical interpretation}

All experiments were performed in triplicate and the data is presented as mean \pm SEM. To measure the statistical significance of the infection assays results, we used two tailed Student's t-test. A group difference was assumed to be statistically significant when $\mathrm{p}<0.05$. All results were expressed as means $\pm \mathrm{SD}$.

\section{Results and Discussions}

All bacterial counts are expressed as $\log \mathrm{CFU} / \mathrm{ml}$ and are the means of 3 replicates.

C. jejuni and LAB behave differently in the presence of camelina oil.

On one hand, camelina oil inhibits the growth of $C$. jejuni and shows a slight but not significant reduction. There was a slightly greater difference between the mean of inoculum level counts (5.80 log/CFU) and the mean of counts after treatment with camelina oil $5.37 \mathrm{log} / \mathrm{CFU}$, with a difference of $0,42 \log / \mathrm{CFU}$, versus $\mathrm{LSD}=0,38$, but with $\mathrm{p}<0,05$ (Figure 1).

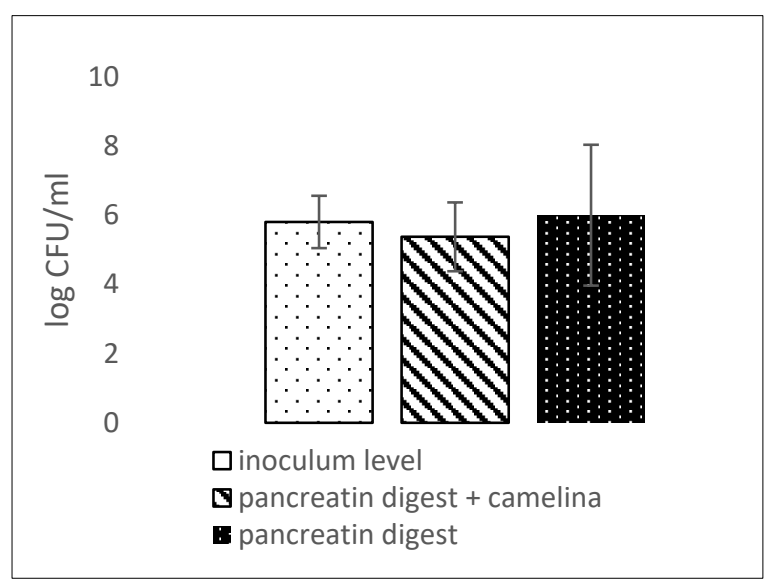

Figure 1. The effect of camelina oil on Campylobacter jejuni in a pig digestion model. Error bars represent SEM.

On the other hand, when LABs were exposed to camelina oil a significant growth occurred during the incubation period (Figure 2), with $0.49 \mathrm{log} / \mathrm{CFU}$ increase in the incubated sample containing camelina oil compared to the control (pancreatin solution only) (Figure 3).

Although the reduction of $C$. jejuni in the presence of camelina oil was not statistically significant, the results show an antimicrobial effect of camelina oil which, with further research, could be enhanced.

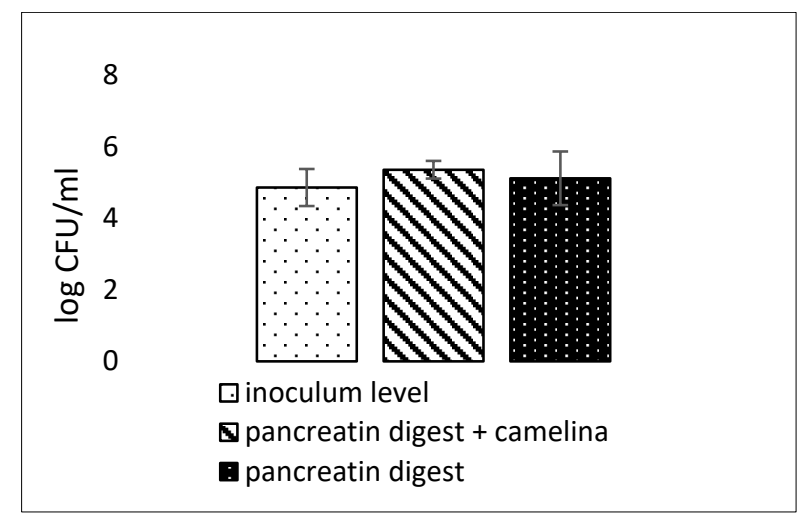

Figure 2. The effect of camelina oil on lactic acid bacteria in a pig digestion model. Error bars represent SEM.

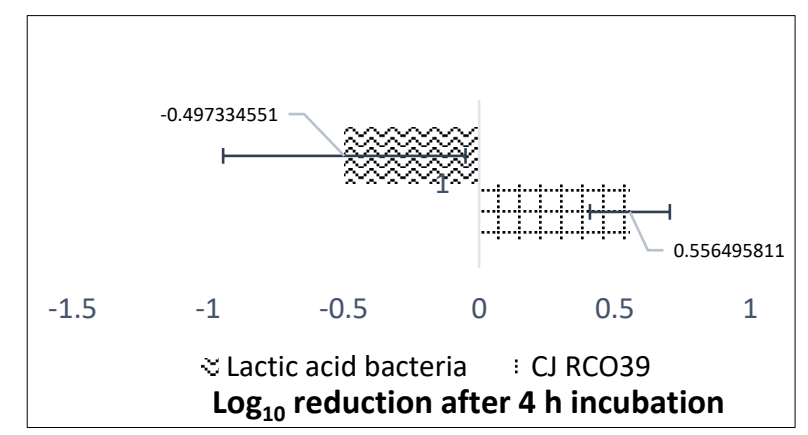

Figure 3. Logarithmic reduction comparison of lactic acid bacteria and $C$. jejuni (RCO39) when exposed to camelina oil. 
According to Lee et al. (2002), a synergistic effect between linolenic acid and monoglycerides such as glycerol laurate or glycerol myristate can occur against certain food-borne microorganisms. Bacillus cereus and Salmonella typhimurium, both Gram + , were the main focus of his research. While the synergistic antimicrobial effect on these microorganisms was superior, there was evidence that some antimicrobial effect, albeit inferior, is also present against other Gram - microorganisms, including E. coli. [18]

In the context of this paper, these findings raise the question whether the synergistic effect of the various fatty acids in camelina oil combined with other compounds has a significantly different impact on microorganisms which develop food-borne diseases. Because LABs are Gram + bacteria, the cytoplasmic membrane is inside the peptidoglycan layer, which could provide, on the one hand, protection against the antimicrobial effects of the fatty acids in camelina oil and on the other hand, the presence of amino-acids and other compounds in camelina oil might nourish LAB. However, the addition of other substances in an attempt to further inhibit $C$. jejuni growth, in the way Lee added monoglycerides, could adversely inhibit the growth of LABs. This is a possible, if not compulsory, further direction of research.

Regarding the limitations of this study, we must mention the lack of results on E. coli 11601, Salmonella E182 and Streptococcus suis 9683, both strains obtained from AFBI, Food Microbiology Branch culture collection. The reasons for this may be the structural differences of these bacteria, as well as the lack of another compound which could enhance the antimicrobial effect of camelina oil.

It is important to mention the inability to produce a stable emulsion of camelina oil and RPMI 1640 medium (ThermoFisher Scientific). Initially we made various attempts, using different concentrations of oil and lecithin. The only stable combination was that of $8,1 \mathrm{ml}$ RPMI, $0,9 \mathrm{~g}$ lecithin and $1 \mathrm{ml}$ camelina oil. However, even a minimal dilution of this emulsion resulted in an unstable compound, which could not be used to further determine the MIC (minimum inhibitory concentration). This led to a change of perspective, which ultimately resulted in the method used in this study.

In close relation with this issue, the minimum oil concentration remains undiscovered. The composition of camelina oil may have important variations depending on the crop in terms of soil and climate conditions, as well as oil extraction methods. Only after a degree of standardization in camelina crops and oil is ensured, can we truly make progress regarding the minimum oil concentration and its antimicrobial potential.

\section{Conclusions}

$>$ The free fatty acids from camelina oil show potential to reduce the numbers of Campylobacter jejuni in vitro and further research should be made to assess the antimicrobial activity of camelina oil in vivo and to determine the mechanism of inactivation.

$>$ Camelina oil had no deleterious effect on the lactic acid bacteria studied here so may be used without raising concerns about harming probiotic bacteria.

$>$ Further in vitro research could be carried out to determine if a higher level of reduction of $C$. jejuni could be obtained in presence of both camelina oil and probiotic LABs.

$>$ Having an antimicrobial effect, low level of glucosinolates and a low content of erucic acid, camelina's position as an industrial crop should be reconsidered to a more "feed friendly" crop.

\section{Acknowledgements}

This paper was funded through a research project won at an internal research competition within Banat University of Agricultural Sciences and Veterinary Medicine "King Michael I of Romania" from Timisoara.

\section{Conflict of Interest}

The authors have no conflict of interest to declare.

\section{References}

1. JOHNSON, D.L. 2006. Introduction and production of Camelina. Montana State University, Northwest Agricultural Research Center, Kalispell, MT.

2. ERIC J. MURPHY, 2016. Chapter-8 Camelina (Camelina Sativa) in: Thomas A. McKeon, Douglas G. Hayes, Randall J. Weselake (Eds.) Industrial oil crops 2016, Academic Press and AOCS Press, 207-230.

3. HUMPHREY T., O'BRIEN S., MADSEN M. 2007. Campylobacters as zoonotic pathogens: a food production perspective. Int. J. Food Microbiol. 117: 237-257

4. A. CORRIGAN, B.J. FAY, N. CORCIONIVOSCHI, R.A. MURPHY. Effect of yeast mannan-rich fractions on reducing Campylobacter colonization in broiler chickens. The Journal of Applied Poultry Research, Vol. 26 (3), 350-357.

5. GANAN M., SILVÁN J.M., CARRASCOSA A.V., MARTÍNEZ-RODRÍGUEZ A.J. 2012. Alternative strategies to use antibiotics or chemical products for 
controlling Campylobacter in the food chain. Food Control, 24:6-14.

6. MEUNIER M., GUYARD-NICODEME M., DORY D., CHEMALY M. 2016. Control strategies against Campylobacter at the poultry production level: Biosecurity measures, feed additives and vaccination. J. Appl. Microbiol, 120:11390-1173.

7. F. IMBREA, S. JURCOANE, H. V. HĂLMĂJAN, M. DUDA, L. BOTOŞ. Camelina sativa: a new source of vegetal oils. Romanian Biotechnological Letters, Vol. 16, No. 3, 2011.

8. SL. BATRINA, S JURCOANE, I POPESCU, F MARIN, IM IMBREA, F. CRISTA, F. IMBREA. Camelina sativa: a study on amino acid content. Romanian Biotechnological Letters, Vol. 25, No. 1, 2020.

9. F. IMBREA, S. JURCOANE, G. POP, IM. IMBREA, L. BOTOS, F. CRISTA, L. SMULEAC. Valorising municipal sludge as fertilizer in Camelina sativa (L.) Crantz. Romanian Biotechnological Letters, Vol. 22, No. 4, 2017.

10. A. SAMPATH. Chemical characterization of camelina seed oil. Master of Science Thesis. State University of New Jersey, 2009.

11. A.P. DESBOIS, V.J. SMITH. Antibacterial free fatty acids: activities, mechanisms of action and biotechnological potential. Appl Microbiol Biotechnol, 2010 Feb; 85(6):1629-42.

12. S.M. GUPTA, K. KUMAR, M. NASIM. Methanolic Seed extract of Camelina shows potential antimicrobial and antioxidant activity against pathogens. DRDO Technology Spectrum: 123-129, 2015.

13. A. SELLAM, B. IACOMI, P. HUDHOMME, P. SIMONEAU. In vitro antifungal activity of brassinin, camalexin and two isothiocyanates against the crucifer pathogens Alternaria brassicicola and Alternaria brassicae. Plant Pathol., 2007, 56, 296- 301.

14. H.U STOTZ, Y. SAWADA, Y. SHIMADA. Role of camalexin, indole glucosinolates, and side chain modification of glucosinolate-derived isothiocyanates in defense of Arabidopsis against Sclerotinia sclerotiorum. Plant J., 2011, 67, 81-93.

15. E.E. ROGERS, J. GLAZEBROOK, F.M. AUSUBEL. Mode of action of the Arabidopsis thaliana phytoalexin camalexin and its role in Arabidopsis - pathogen interactions. Mol. Plant Microbe Interact., 1996, 9, 748-757

16. I. AHUJA, R. KISSEN, A.M. BONES. Phytoalexins in defence against pathogens. Trends in Plant Science, 2012, 17(2), 1360-1385.

17. A.PLAPER, M. GOLOB, I. HAFNER, M. OBLAK, T. SOLMAJER, R. JERALA. Characterization of quercetin binding site on DNA gyrase. Biochem. Biophys. Res. Commun., 2003, 306, 530-536.

18. J.Y LEE, Y.S KIM, D.H. SHIN. Antimicrobial synergistic effect of linolenic acid and monoglyceride against Bacillus cereus and Staphilococcus aureus. J. Agric. Food Chem., 2002, 50, 2193-2199 2193. 